\title{
Impact of Various Organic Manures on Growth, Growth Attributes and Quality of Cabbage (Brassica oleracea var. capitata L.)
}

\author{
Arshpreet Kaur* \\ Department of Agriculture, Khalsa College, Amritsar, India \\ *Corresponding author
}

\section{A B S T R A C T}

\section{Keywords}

Cabbage, B:C ratio, Biofertilizer,

Organic manures, Yield

Article Info

Accepted:

04 March 2020

Available Online:

10 April 2020
An investigation entitled "Impact of different organic manures on performance of cabbage (Brassica oleracea var. capitata L.)" under field conditions was conducted in October 2017-2018 at Department of Horticulture, Khalsa College Amritsar (Punjab). The investigation was laid out in RBD with eleven treatments replicated three times with spacing $45 \times 45 \mathrm{~cm}$. The eleven treatments combinations were $T_{1}$ - Recommended dose of fertilizers, $\mathrm{T}_{2}-100 \% \mathrm{~N}$ by Vermicompost, $\mathrm{T}_{3}-100 \% \mathrm{~N}$ by Poultry manure, $\mathrm{T}_{4}-100 \% \mathrm{~N}$ by Farmyard manure, $\mathrm{T}_{5^{-}} 100 \% \mathrm{~N}$ by Vermicompost + Azotobacter, $\mathrm{T}_{6^{-}} 100 \% \mathrm{~N}$ by Poultry manure+Azotobacter, $\mathrm{T}_{7^{-}} 100 \% \mathrm{~N}$ by Farmyard manure+Azotobacter, $\mathrm{T}_{8^{-}} 75 \% \mathrm{~N}$ by Vermicompost+ Azotobacter, $\mathrm{T}_{9^{-}} 75 \% \mathrm{~N}$ by Poultry manure+Azotobacter, $\mathrm{T}_{10^{-}} 75 \% \mathrm{~N}$ by Farmyard manure+Azotobacter, $\mathrm{T}_{11^{-}}$Control. Among various treatments $\mathrm{T}_{1}(\mathrm{RDF})$ proved to be significant over rest of the treatments as it registered maximum growth parameters. Maximum plant height at harvest was recorded to be $(30.19 \mathrm{~cm})$, plant spread at harvest $(46.74 \mathrm{~cm})$, leaf length with petiole at harvest $(32.34 \mathrm{~cm})$, leaf breadth $(24.37 \mathrm{~cm})$, leaf area $\left(147.65 \mathrm{~cm}^{2}\right)$, total number of leaves (31.85), total number of folded leaves (18.30), total number of unfolded leaves (13.56), stem length (NS), TSS content $\left(4.94^{\circ} \mathrm{Brix}\right)$, ascorbic acid content $(44.05 \mathrm{mg} / 100 \mathrm{~g})$ was obtained in RDF. Among organic manures, poultry manure alone proved to be beneficial than Vermicompost and Farmyard manure, as it improved the growth and yield of cabbage and also gave maximum returns as compared. Among organic manures and biofertilizers, poultry manure along with Azotobacter performed better than Azotobacter combinations with Vermicompost and Farmyard manure. Among organic manure treatment $\mathrm{T}_{6}$ (4 tonnes/ha poultry manure+Azotobacter) was found to be more economical as it solve the purpose both ways one being changing the trend of using more inorganic fertilizers towards organic manures and second being getting higher returns with $\mathrm{B}: \mathrm{C}$ ratio (4.84).

\section{Introduction}

Cabbage (Brassica oleracea var. capitata L.) is one of the esteemed leafy vegetable, which is widely cultivated throughout the globe. It belongs to the family Cruciferae and genus Brassica which is consumed fresh as well as in processed form in different countries of the world (Haque et al., 2015, Best, 2000). The Food and Agriculture organization has 
identified cabbage among one of the top twenty vegetables (Olaniyi and Akanbi, 2008). In India the area under cabbage cultivation is around 4 lac hectare with 9039‘000 MT production during 2013-2014 (Anonymous, 2014). Cabbage is an important vegetable crop that grows well in climatic conditions of Punjab with good yield and productivity. Punjab produces 87.19 thousand tonnes from an area of 4.95 thousand ha with an average yield of 17.61 thousand MT/ha (Anonymous, 2014). Major cabbage producing districts include Amritsar, Patiala, Jalandhar and Ludhiana.

Nutrient management plays a crucial role for the improvement of cabbage yield and production. A remarkable effect on the physiological attributes after the incorporation of organic nutrients especially in the form of vermicompost, farmyard manure, poultry manure and biofertilizer has been noticed in various vegetables. Apparently, inorganic fertilizers impair the crop health due to of residual effect but such kinds of issues are not evident in case of organic fertilizer (Tindal 2000). The farmers supplement chemical fertilizer as a readily available source for nutrients but they do not apply it in balanced proportion (BARC, 2005). Despite of the balanced use of sole chemical fertilizer, high yield level could not be attained over years due to deterioration in soil physical, chemical and biological properties (Khan et al., 2008). However, some studies have suggested that excessive use of those agrochemicals may actually aggravate pest problem in the long run (Altieri and Nocholls, 2003).

\section{Materials and Methods}

The field experiment was conducted at an experimental farm area of Department of Horticulture, Khalsa College, Amritsar during 2017-18 located $31^{\circ}-38^{\prime} \mathrm{N}$ latitude and $74^{\circ}$ $52^{\prime} \mathrm{E}$ longitude with an elevation of $236 \mathrm{~m}$
MSL and represents the sub-tropical climate and humid zone of Punjab region in order to work impact of various sources of organic manures for obtaining higher head yield of cabbage. The soil of an experimental plot was sandy loam in texture with $\mathrm{pH} 8.40$, organic carbon (0.40-0.75\%), medium in available $\mathrm{N}$ $(0.28 \%)$, available $\mathrm{P}(16 \mathrm{~kg} / \mathrm{ha})$ and available $\mathrm{K}(175 \mathrm{~kg} / \mathrm{ha})$. The experiment was laid in a randomized block design with three replications having 11 treatments comprising different combinations of organic sources and Azotobacter viz. 125:62.5:62.5 NPK per hectare through RDF $\left(\mathrm{T}_{1}\right), 8$ tonnes/ha of $\mathrm{N}$ through vermicompost $\left(\mathrm{T}_{2}\right), 4$ tonnes/ha of $\mathrm{N}$ through poultry manure $\left(\mathrm{T}_{3}\right), 25$ tonnes/ha of $\mathrm{N}$ through farmyard manure $\left(\mathrm{T}_{4}\right), 8$ tonnes/ha of $\mathrm{N}$ through vermicompost + Azotobacter $\left(\mathrm{T}_{5}\right), 4$ tonnes/ha of $\mathrm{N}$ through poultry manure + Azotobacter $\left(\mathrm{T}_{6}\right), 25$ tonnes/ha of $\mathrm{N}$ through farmyard manure + Azotobacter $\left(\mathrm{T}_{7}\right), 6$ tonnes/ha of $\mathrm{N}$ through vermicompost + Azotobacter $\left(\mathrm{T}_{8}\right), 3$ tonnes/ha of $\mathrm{N}$ through poultry manure + Azotobacter $\left(\mathrm{T}_{9}\right)$ and 18 tonnes/ha of $\mathrm{N}$ through farmyard manure $\left(\mathrm{T}_{10}\right)$ and control $\left(\mathrm{T}_{11}\right)$.

Cabbage seedling roots were inoculated with Azotobacter solution@ @-5 ml per litre of water. The solution was dissolved in water and the seedlings of cabbage were dipped in the solution for 30 minutes before transplanting. Cabbage (Golden Acre) was transplanted at $45 \times 45 \mathrm{~cm}$ spacing on $1^{\text {st }}$ of October and harvested at fully matured stage. Selected and tagged plants were left in the field for head production during winter. All other cultural practices were followed as per standard recommendations. Absolute growth rate (AGR) was calculated using the formula (Wareing and Philips, 1981):

$$
\text { Absolute growth rate }=\frac{\mathrm{H}_{2}-\mathrm{H}_{1}}{\mathrm{~T}_{2}-\mathrm{T}_{1}}
$$

The data was analyzed as per the standard procedure for Analysis of Variance 
(ANOVA). The difference in the treatment mean was tested by using critical difference (CD) at $5 \%$ level of probability.

\section{Results and Discussion}

\section{Growth parameters}

Plant height is a reliable index of plant growth that indicates the vigor, strength and adaptability of the crop to the existing environment. It is evident from the Table 1 that plant height was significantly affected by different manure and fertilizer combinations under the present study. It is evident that plant height was highest with recommended dose of nutrients $\left(\mathrm{T}_{1}\right)$ i.e. $30.19 \mathrm{~cm}$ at 60 DAT. On the other hand lowest plant height at 60 DAT was recorded to be $26.23 \mathrm{~cm}$ with control treatment. The second highest plant height was recorded $29.66 \mathrm{~cm}$ at 60 DAT in $\mathrm{T}_{6}$ (4t/ha poultry manure + Azotobacter $)$ which was statistically similar with $\mathrm{T}_{1}$. At harvesting $\mathrm{T}_{3}, \mathrm{~T}_{5}, \mathrm{~T}_{6}, \mathrm{~T}_{8}$ and $\mathrm{T}_{9}$ are at pat to $\mathrm{T}_{1}$. Present findings on plant height are also in conformity with Souza et al., (2008), Hasan and Solaiman (2012). The data in Table 1 reveal that the maximum plant spread at 60 DAT was recorded in $T_{1}(\mathrm{RDF})$ i.e. $46.74 \mathrm{~cm}$ at 60 DAT. Whereas the second highest plant spread was obtained in $\mathrm{T}_{6}$ (4 tonnes/ha poultry manure + Azotobacter) i.e. $45.33 \mathrm{~cm}$ at 60 DAT. At 60 DAT $\mathrm{T}_{3}, \mathrm{~T}_{5}, \mathrm{~T}_{6}$ and $\mathrm{T}_{9}$ are significantly at par to $T_{1}$. Whereas, the lowest plant spread was recorded in $\mathrm{T}_{11}$ i.e. $32.73 \mathrm{~cm}$ at harvesting. The results in respect of this character are in complete agreement with the findings of Bhagavantagoudra and Rokhade (2002) and Choudhary and Choudhary (2005) for cole crops. Table 1 describe that significant variation was observed for leaf length with petiole at different stages after transplanting. It was observed that the highest leaf length with petiole was recorded with recommended dose of fertilizers $\left(T_{1}\right)$ i.e. $32.34 \mathrm{~cm}$ at 60 DAT followed by treatment of poultry manure @4 tonnes along with Azotobacter $\left(\mathrm{T}_{6}\right)$. At 60 DAT $\mathrm{T}_{2}, \mathrm{~T}_{3}, \mathrm{~T}_{5}, \mathrm{~T}_{6}, \mathrm{~T}_{7}$ and $\mathrm{T}_{9}$ are statistically identical to $\mathrm{T}_{1}$. The lowest leaf length with petiole was $20.71 \mathrm{~cm}$ at 60 DAT in control. The results obtained under the present experiment were also supported by Souza et al., (2008), Hasan and Solaiman (2012). Leaf breadth significantly varied with different organic manures at different days after transplanting (DAT) as described in Table 1. It was measured that highest leaf breadth was obtained with the use of recommended dosage of nutrients $\left(\mathrm{T}_{1}\right)$ and that was $24.37 \mathrm{~cm}$ at 60 DAT respectively. $\mathrm{T}_{1}$ was followed by $\mathrm{T}_{6}$ (poultry manure @ 4 tonnes + Azotobacter). On the other hand lowest leaf breadth i.e. $18.24 \mathrm{~cm}$ at 60 DAT was obtained with control treatment $\left(\mathrm{T}_{11}\right)$. At 60 DAT $\mathrm{T}_{2}, \mathrm{~T}_{3}, \mathrm{~T}_{5}, \mathrm{~T}_{6}, \mathrm{~T}_{7}$ and $\mathrm{T}_{9}$ are statistically identical to $\mathrm{T}_{1}$. The results obtained under present experiment were also supported by Souza et al., (2008), Hasan and Solaiman (2012). Leaf area is an important plant growth indices determining the capacity of plant in trapping solar energy for photosynthesis and has marked influence on growth and yield of cabbage crop. Table 1 represents the leaf area at various growth stages. The highest leaf area at 60 DAT was $147.65 \mathrm{~cm}^{2}$, which was obtained due to application of RDF $\left(\mathrm{T}_{1}\right)$. It was followed by $\mathrm{T}_{6}$ which recorded leaf area of $137 \mathrm{~cm}^{2}$ at 60 DAT. However, least leaf area was recorded in $\mathrm{T}_{11}$ i.e. absolute control which was 106.33 $\mathrm{cm}^{2}$ at 60 DAT. At 60 DAT $\mathrm{T}_{3}$, $\mathrm{T}_{5}$ and $\mathrm{T}_{6}$ are statistically identical to $\mathrm{T}_{1}$. It was observed from Table 1 that no significant effect was seen in stem length at 60 DAT. Islam (2011), Sajib et al., (2015) also supported the same results in their study. The number of leaves per plant is an important parameter considering the highest performance of cabbage yield. It is evident from Table 2 that the highest number of leaves per plant was obtained by the use of recommended dose of fertilizer $\left(\mathrm{T}_{1}\right)$ and the 
highest number of leaves was 31.85 at harvest respectively. $T_{1}$ was statistically identical with $\mathrm{T}_{6}$ comprising treatment of 4 tonnes/ha poultry manure and Azotobacter. The total number of leaves measured at harvest were 30.00 in $\mathrm{T}_{6}$ (4 tonnes/ha poultry manure and Azotobacter). The lowest number of leaves was found to be 24.56 at harvest respectively with control treatment $\left(\mathrm{T}_{11}\right)$. The result obtained from the experiment on total number of leaves per plant was in conformity with Vimla (2006), Pankaj (2006) and Muhammad and Javed (2001).

The number of folded leaves per plant is an important parameter considering the highest performance of cabbage yield. It is evident from Table 1 that the highest number of leaves per plant was obtained by the use of recommended dose of fertilizer $\left(T_{1}\right)$ and the highest number of folded leaves was 18.30 at harvest. $T_{1}$ was statistically identical with $T_{6}$ comprising treatment of 4 tonnes/ha poultry manure and Azotobacter. The total number of folded leaves measured at harvest were 17.96 in $\mathrm{T}_{6}$ (4 tonnes/ha poultry manure and Azotobacter). The lowest number of folded leaves was found to be 14.00 at harvest in control treatment $\left(\mathrm{T}_{11}\right)$. This finding was in agreement with those reported by Singh et al., (2009) and Kumar et al., (2010) in cauliflower, Choudhary et al.,., 2012 and Mohanpatra et al.,., 2013. The data from Table 1 reveal that no significant effect was observed in number of unfolded leaves in cabbage at harvest due to various organic amendments. Absolute Growth Rate (AGR) is the change in actual growth over time. As clear from the Chart 1, treatment combination $\left(\mathrm{T}_{7}\right)$ recorded highest growth. It might be due to slow decomposition of farmyard manure at initial stages which later became available to plants leading to increased growth over time. Hence, low initial growth due to FYM lead to lower yield than other manures.

Table.1 Effect of different organic manures in AGR of cabbage

\begin{tabular}{|c|c|c|c|}
\hline & Treatment & 45DAT & 60DAT \\
\hline $\mathbf{T}_{\mathbf{1}}$ & RDF & 0.21 & 0.37 \\
\hline $\mathbf{T}_{\mathbf{2}}$ & 100\% VC & 0.24 & 0.36 \\
\hline $\mathbf{T}_{\mathbf{3}}$ & 100\% PM & 0.26 & 0.36 \\
\hline $\mathbf{T}_{\mathbf{4}}$ & 100\%FYM & 0.25 & 0.36 \\
\hline $\mathbf{T}_{\mathbf{5}}$ & $100 \% \mathrm{VC}+\mathrm{AZB}$ & 0.31 & 0.36 \\
\hline $\mathbf{T}_{\mathbf{6}}$ & $100 \% \mathrm{PM}+\mathrm{AZB}$ & 0.27 & 0.36 \\
\hline $\mathbf{T}_{\mathbf{7}}$ & $100 \% \mathrm{FYM}+\mathrm{AZB}$ & 0.37 & 0.27 \\
\hline $\mathbf{T}_{\mathbf{8}}$ & $75 \% \mathrm{VC}+\mathrm{AZB}$ & 0.32 & 0.50 \\
\hline $\mathbf{T}_{\mathbf{9}}$ & $75 \% \mathrm{PM}+\mathrm{AZB}$ & 0.27 & 0.39 \\
\hline $\mathbf{T}_{\mathbf{1 0}}$ & $75 \% \mathrm{FYM}+\mathrm{AZB}$ & 0.28 & 0.36 \\
\hline $\mathbf{T}_{\mathbf{1 1}}$ & Control & 0.31 & 0.36 \\
\hline
\end{tabular}


Table.2 Effect of different organic manures on growth and quality of cabbage

\begin{tabular}{|c|c|c|c|c|c|c|c|c|c|c|c|}
\hline & $\begin{array}{c}\text { Plant } \\
\text { height } \\
(\mathrm{cm})\end{array}$ & $\begin{array}{c}\text { Plant } \\
\operatorname{spread}(\mathrm{cm})\end{array}$ & $\begin{array}{l}\text { Leaf length } \\
\text { with petiole } \\
\text { (cm) }\end{array}$ & $\begin{array}{c}\text { Leaf } \\
\text { breadth } \\
\text { (cm) }\end{array}$ & $\begin{array}{l}\text { Leaf } \\
\text { area } \\
\left(\mathrm{cm}^{2}\right)\end{array}$ & $\begin{array}{l}\text { Stem } \\
\text { length } \\
(\mathrm{cm})\end{array}$ & $\begin{array}{c}\text { Total } \\
\text { number } \\
\text { of leaves }\end{array}$ & $\begin{array}{l}\text { No. of } \\
\text { folded } \\
\text { leaves }\end{array}$ & $\begin{array}{c}\text { No. of } \\
\text { unfolded } \\
\text { leaves }\end{array}$ & $\begin{array}{c}\text { TSS } \\
\left({ }^{\circ} \text { Brix }\right)\end{array}$ & $\begin{array}{c}\text { Vitamin } \\
\mathrm{C} \\
(\mathrm{mg} / \mathbf{1 0 0 g})\end{array}$ \\
\hline Treatments & 60DAT & 60DAT & 60DAT & 60DAT & 60DAT & 60DAT & 60DAT & 60DAT & 60DAT & & \\
\hline $\mathrm{T}_{1}$ & 30.19 & 46.74 & 32.34 & 24.37 & 147.65 & 2.44 & 31.85 & 18.30 & 15.22 & 4.94 & 39.92 \\
\hline $\mathbf{T}_{2}$ & 27.98 & 41.45 & 28.62 & 21.23 & 119.49 & 2.22 & 27.00 & 14.78 & 13.89 & 4.17 & 42.92 \\
\hline $\mathbf{T}_{\mathbf{3}}$ & 29.26 & 43.51 & 30.48 & 23.83 & 131.35 & 2.27 & 28.48 & 15.56 & 14.59 & 4.67 & 43.88 \\
\hline $\mathbf{T}_{4}$ & 26.74 & 38.29 & 25.69 & 20.22 & 114.61 & 2.15 & 25.00 & 13.67 & 13.00 & 3.24 & 42.67 \\
\hline $\mathbf{T}_{5}$ & 29.47 & 42.55 & 29.67 & 23.04 & 133.47 & 2.33 & 29.04 & 16.70 & 14.00 & 4.70 & 43.86 \\
\hline $\mathbf{T}_{6}$ & 29.66 & 45.33 & 31.50 & 24.07 & 137.00 & 2.41 & 30.00 & 17.96 & 14.78 & 4.83 & 44.05 \\
\hline $\mathbf{T}_{7}$ & 27.27 & 39.35 & 29.96 & 21.90 & 120.40 & 2.17 & 28.00 & 15.89 & 13.78 & 4.50 & 43.02 \\
\hline $\mathbf{T}_{8}$ & 28.91 & 39.04 & 27.59 & 20.86 & 116.96 & 2.17 & 27.15 & 15.15 & 13.67 & 3.60 & 42.52 \\
\hline $\mathbf{T}_{9}$ & 29.38 & 42.89 & 30.34 & 21.09 & 130.07 & 2.22 & 29.41 & 16.37 & 14.70 & 3.67 & 43.74 \\
\hline $\mathbf{T}_{10}$ & 26.46 & 37.11 & 24.71 & 20.48 & 111.96 & 2.02 & 26.07 & 14.29 & 13.45 & 3.20 & 42.19 \\
\hline $\mathbf{T}_{11}$ & 26.23 & 32.73 & 20.71 & 18.24 & 106.33 & 1.95 & 24.56 & 14.00 & 12.22 & 2.98 & 42.15 \\
\hline$C D(p=0.05)$ & 1.28 & 5.24 & 3.76 & 3.36 & 17.00 & NS & 2.76 & 0.54 & NS & 0.59 & 1.13 \\
\hline
\end{tabular}

$T_{1}$ - Recommended doze of nutrients; $T_{2^{-}} 100 \%$ of $N$ by VC; $T_{3}-100 \%$ of $N$ by PM; $T_{4^{-}} 100 \%$ of $N$ by FYM; $T_{5^{-}} 100 \%$ of $N$ by VC+AZB; $T_{6}-100 \%$ of $N$ by $P M+A Z B ; T_{7-}^{-100 \%}$ of $N$ by FYM+AZB; $T_{8^{-}} 75 \%$ of $N$ by VC+AZB; $T_{9^{-}} 75 \%$ of $N$ by PM+AZB; $T_{10^{-}} 75 \%$ of $N$ by FYM+AZB; $T_{11^{-}}$Control 
Fig.1 Effect of different organic manures in AGR of cabbage

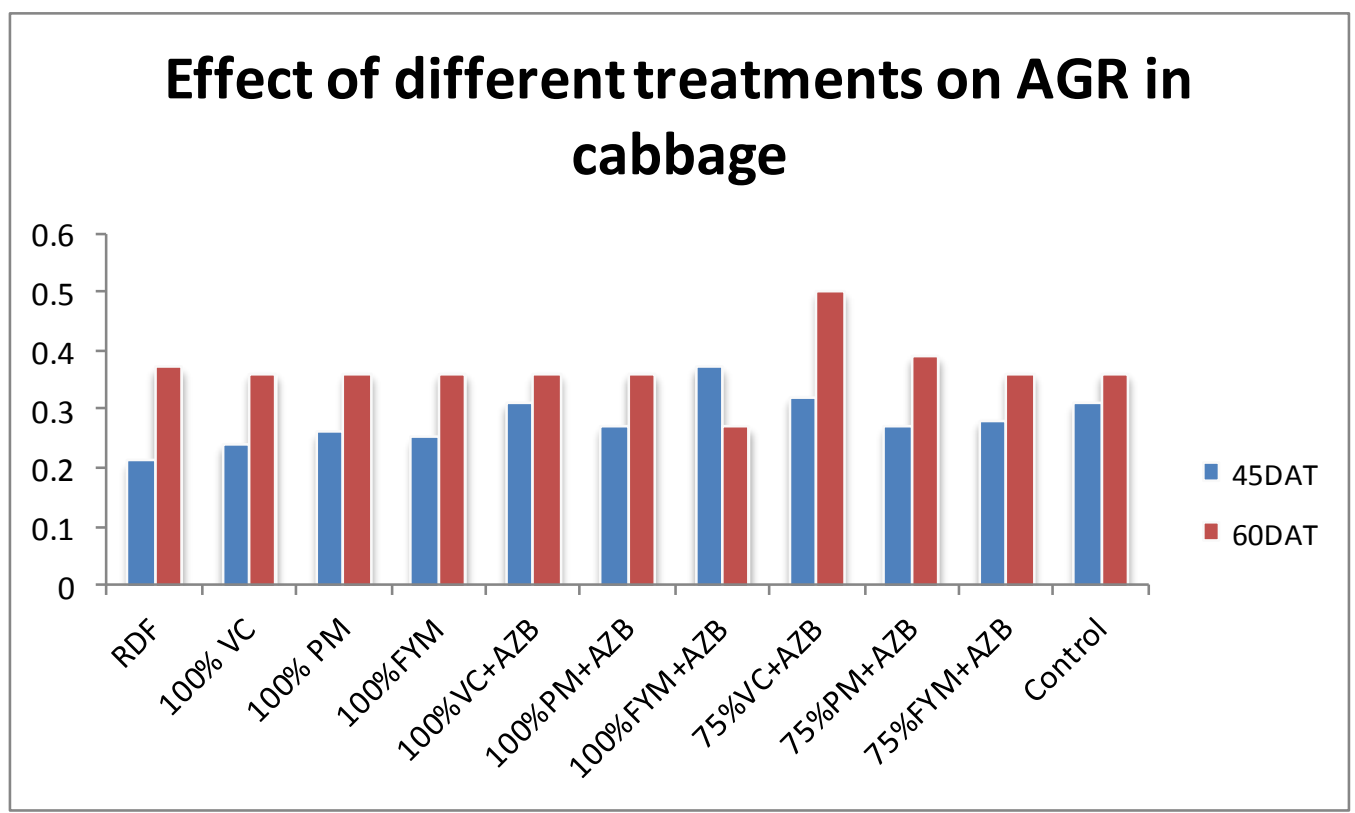

\section{Quality parameters}

The use of different organic sources and inorganic sources showed disparities in TSS content of cabbage has been presented in Table 1. The highest TSS content $4.94^{\circ}$ Brix was recorded in $\mathrm{T}_{1}$ (recommended dose of fertilizers) followed by $4.83^{\circ}$ Brix in $\mathrm{T}_{6}(4$ tonnes/ha poultry manure + Azotobacter $)$ and $4.70^{\circ} \mathrm{Brix}$ in $\mathrm{T}_{5} \quad(8$ tonnes/ha vermicompost + Azotobacter $) . \mathrm{T}_{3}, \mathrm{~T}_{5}, \mathrm{~T}_{6}$ and $\mathrm{T}_{7}$ are statistically at par with $\mathrm{T}_{1}$. Whereas lowest TSS content $2.98^{\circ}$ Brix was recorded in control. Different nutrient sources affected the vitamin $\mathrm{C}$ content significantly in cabbage. Hiwale et al., (2010), Yano et al., (1981) also reported that the application of organic manures increased glucose and fructose content in cabbage. Data from Table 1 reveal that the maximum vitamin $\mathrm{C}$ content i.e. $44.05 \mathrm{mg} / 100 \mathrm{~g}$ was recorded in $\mathrm{T}_{6}$ (4t/ha poultry manure + Azotobacter $)$ followed by $43.88 \mathrm{mg} / 100 \mathrm{~g}$ in $\mathrm{T}_{3}$ (4t/ha poultry manure), $43.86 \mathrm{mg} / 100 \mathrm{~g}$ in $\mathrm{T}_{5}(8 \mathrm{t} / \mathrm{ha}$ vermicompost + Azotobacter $), \quad 43.02$ $\mathrm{mg} / 100 \mathrm{~g}$ in $\mathrm{T}_{7}$ and $43.74 \mathrm{mg} / 100 \mathrm{~g}$ in $\mathrm{T}_{9}$ (3t/ha poultry manure + Azotobacter) $\mathrm{T}_{3}, \mathrm{~T}_{5}$, $\mathrm{T}_{7}$ and $\mathrm{T}_{9}$ are statistically at par with $\mathrm{T}_{6}$. However, minimum vitamin $\mathrm{C}$ content was $39.86 \mathrm{mg} / 100 \mathrm{~g}$ in $\operatorname{RDF}\left(\mathrm{T}_{1}\right)$. Bahadur et al., (2003) in broccoli and Shree et al., (2014) in cauliflower also reported the similar results. Jaipal et al., (2011) gave similar results that significantly higher ascorbic acid was recorded in integrated nutrient management in comparison to sole organic manures. Verma et al., (2004) also concluded the same in their experiment in cabbage. Higher growth and growth characters due to RDF can be attributed to easy availability of nutrients required by plants leading to profuse growth. Among organic manures along with Azotobacter, superior results due to Poultry manure might be due to higher $\mathrm{N}$ content and quick availability.

From the experiment trial it can be concluded that:

Among various treatments, $\mathrm{T}_{1}(\mathrm{RDF})$ was found to be better as it yielded maximum growth as well as other growth characters. 
On the other hand, in case of organic manures and biofertilizers combinations, the treatment $\mathrm{T}_{6}(100 \% \mathrm{~N}$ by poultry manure + Azotobacter) was found to be more economical as it solved the purpose both ways one being changing the trend of using more inorganic fertilizers towards organic manures and second being getting higher returns and $\mathrm{B}: \mathrm{C}$ ratio $(3.84)$.

\section{References}

Altieri, M. A., Nicholls, C. I., 2003 Soil fertility management and insect pests: harmonizing soil and plant health in agro ecosystems. Soil Till Res 72:203-211.

Anonymous (2014). Indian Horticulture Database, National Horticulture Board, Ministry of Agriculture, Government of India, 85, Institutional Area, Sector-18, Gurgaon-122015, India, 141.

BARC., 2005 Fertilizer Recommendation Guide. Bangladesh Agri Res council Farmgate, Tejgoan, Dhaka, Bangladesh p:196.

Best, K., 2000 Adaptation of Cabbage Varieties, ARP Training Reports. AVRDC-AFRICA Reg Prog, Arusha, Tanzania p:10.

Bhagavantagoudra, K. H., and Rokhade, A. K., 2001 Economics of Azospirillium inoculation to cabbage. Karnataka J of Agr Sci 15(2): 413415.

Chaudhary, M. M., Bhanvadia, A. S., and Parmar, P. N., 2015 Effect of Integrated nutrient management on growth, yield attributes and yield of cabbage (Brassica oleracea var.capitata L.) under Middle Gujarat conditions. Trends in Bio Sci 8(8):2164-2168.

Choudhary, R. K., and Choudhary, D. N., 2005. Effect of different levels of nitrogen and phosphorus on growth, yield and quality of hybrid cabbage. Haryana J of Hort Sci 34(1/2): 145-146.
Haque, A., Bhowal, S. K., Ali M., Robbani M., 2015 Yield and yield attributes of cabbage (Brassica oleracea var. capitata L.) as influenced by soil organic amendments. Basic Res J of Agr Sci 4(12): 339-344.

Hasan, M. R., and Solaiman, A. H. M., 2012 Efficacy of organic and organic fertilizer on the growth of cabbage (Brassica oleracea var.capitata L.). Int J of Agr and crop Sci 4(3):128-138.

Khan, M. S., Shil, N. C., and Noor, S., 2008 Integrated nutrient management for sustainable yield of major vegetable crops in Bangladesh. Bangladesh J of Agri Env 4:81-94.

Olaniyi, J. O., and Akanbi, W. B., 2008 Effect of cultural practice on mineral compositions of cassava peel compost and its effect on the performance of cabbage (Brassica oleracea L). J of applied Biosci 8(1): 272 - 279.

Pankaj, S., 2006 Integrated effect of bioinoculants, organic and inorganic fertilizer on growth and yield of cabbage, Hisar. Crop Res Hisar 32:188-191.

Sajib, K., Dash, P. K., Adhikary, B. and Mannan, M. A., 2015 Yield performance of cabbage under different combinations of manures and fertilizers.

Souza, P. A., Souza, G. L. F. M., Menezes, J. B., and Bezerra, N. F., 2008 Evaluations of cabbage cultivar grown under organic compost and mixed mineral fertilizers. Horticultura Brasileira. 26(1): 143-145.

Tindal, M., 2000 Mineral and organic fertilizing in cabbage. Residual effect for commercial cultivation on yield and quality performance with organic farming. Hort Bras 6:15-20.

Vimla, P., 2006 Effect of rates of organic fertilizers on growth, yield and nutrient content of cabbage (Brassica oleracea var.

Wareing, P. F., and Philips, I. D. J., 1981 Growth and Differentiation in Plants. Pergamon Press, NY.

\section{How to cite this article:}

Arshpreet Kaur. 2020. Impact of Various Organic Manures on Growth, Growth Attributes and Quality of Cabbage (Brassica oleracea var. capitata L.). Int.J.Curr.Microbiol.App.Sci. 9(04): 273-279. doi: https://doi.org/10.20546/ijcmas.2020.904.033 